\section{A Note on Hot Springs in Southeastern Alaska}

In an earlier note ${ }^{1}$ a survey was made of hot springs in interior Alaska which had been reported much earlier by Waring ${ }^{2}$, and in this further account the coverage is extended to southeastern Alaska. Following directions recorded by Waring I attempted to reach four hot springs on Baranof Island. Waring had reported warm water in the first creek on the north side of Gut Bay, but the measured temperatures along both this and the next stream were only $1^{\circ} \mathrm{C}$ to $4^{\circ} \mathrm{C}$.

Baranof Hot Springs on the east side of Baranof Island is still highly-developed commercially as in Waring's day. It has a postoffice, a store, a bath house, many log cabins, and wharfs for servicing fishing boats. The temperature of the springs varies from $45^{\circ} \mathrm{C}$ to $50^{\circ} \mathrm{C}$. The postmaster of the settlement stated that, following an earthquake (registering 7.3 on the Richter scale) on 30 July 1972 , the pattern of flow of some springs changed, new areas of upwelling appeared and algae which had been predominantly brown and black changed to white. These hot springs are too developed commercially to be of much biological interest.

Fog precluded any landing near a hot spring on Fish Bay on the north side of Baranof Island, but aerial-observation photographs suggested that the area marked as a hot spring on the topographic map of the U.S. Geological Survey had been mislocated. It was later confirmed that the area was a mile or two closer to Fish Bay than shown on the map.

Goddard Hot Springs (called Sitka Hot Springs by Waring) is located 16 miles (25 $\mathrm{km}$ ) south of Sitka. The springs issue into a clear area approximately 200 yards $(180 \mathrm{~m})$ square right at the ocean, in the midst of a coniferous forest. Three out of four of the reported springs were located. They had temperatures of $45^{\circ} \mathrm{C}$ to $62^{\circ} \mathrm{C}$, and their respective rates of flow were estimated at 5, 10 and 20 gallons (90 litres) per minute. There was much evidence of previous development, such as building foundations, and also much litter and trash left recently by picknickers and hunters. The area of this spring, once a developed resort, now presents a completely abandoned appearance.

Operating from the research vessel Acona of the Institute of Marine Science of the University of Alaska, I visited a number of hot springs in April 1973 in the company of my colleagues James Anderson and John Manthei. At Bailey Bay Hot Springs we walked the five miles from the beach past Lake Shelokum to the springs in heavy snow. The trail went through snow 4-10 ft. $(1-3 \mathrm{~m})$ deep. An area at the springs of approximately 500 square yards $\left(400 \mathrm{~m}^{2}\right)$ was free of snow, and there was evidence that geese and other birds and animals used the area. A small bath house of the U.S. Forest Service, that probably receives some visitors in the summertime, was barely visible. Several springs issue from a side hill and run down into a small stream which flows into Lake Shelokum. The water of one spring rose up in a fountain about 10 inches $(25 \mathrm{~cm})$ high from between two rocks. Waring recorded a temperature of $88^{\circ} \mathrm{C}$ here, but our thermometer did not register so high.

Bell Island Hot Springs is completely developed commercially with an olympic-size pool and many cabins along a boardwalk. The springs themselves are captured in five cement boxes, and have temperatures ranging from $70^{\circ} \mathrm{C}$ to $74^{\circ} \mathrm{C}$. Alaska Airlines maintains regular tourist flights to these hot springs, and for the fishing in the area. Despite a thorough investigation of the shoreline we were unsuccessul in locating the hot springs listed as "near Saks Cove" on the north side of Behm canal. We then revisited Goddard Hot Springs below Sitka and found temperatures of the three springs there to range from $47^{\circ} \mathrm{C}$ to $65^{\circ} \mathrm{C}$. We made a plant collection and took samples of soil, water and algae, and we saw Canada geese and snipe.

At Fish Bay on the north side of Baranof Island we walked about five miles $(8 \mathrm{~km})$ up the creek to the hot springs, locating them however only through the smell of sulphuretted hydrogen. There are many small hot springs in the district, and clear-cutting has been carried on to the edge of the area affected by them. Most of these springs have temperatures of $24^{\circ} \mathrm{C}$ to $40^{\circ} \mathrm{C}$, and they feed a small creek along a flat valley approx. 75 yards $\times 200$ yards $(70 \mathrm{~m} \times 180 \mathrm{~m})$ draining into Fish Creek. There is evidence of old wooden structures around some springs, but no recent sign of man. We saw signs of deer, bear, snipe and many song birds. These hot springs are difficult to locate without an accurate map or directions, but old logging roads helped us to reach their location.

Tenekee Hot Springs are in the village of Tenekee Springs on Tenekee Inlet. The settlement is built along the beach, and the main spring comes up in a bath house which is owned by the U.S. Forest Service and operated by the local townspeople. The water had a temperature of $42^{\circ} \mathrm{C}$. There are a few other small springs issuing from the hillside just above the village, but nothing of biological 
interest remains there. The residents had no knowledge of the hot springs listed by Waring "at the head of Tenekee Inlet" - they were located in a unique biological setting by a gravel bar on a creek at the foot of a steep hill. The water in the main spring, with old fallen logs in the pool, had a temperature of $76^{\circ} \mathrm{C}$. It ran down a brush-covered gravel slope, eventually disappearing. We found no evidence of other springs below the main spring as pictured by Waring, so evidently there is less flow than there was formerly. We found no evidence of human habitation. In its remote setting, and in its pristine condition, this spring should be saved for future scientific assessment.

Waring lists hot springs at the head of Neka Bay and at the head of Mud Bay on Chichagof Island. Since these two bays head towards each other, and while flying over the area we could locate only one hot spring which was in between the two bays, Waring's citations may have reference to the same hot spring. We walked about five miles $(8 \mathrm{~km})$ up the creek to the area of the hot springs. Bverything was covered with snow except the area around the hot springs. We saw brown bear, deer, geese, cranes and ducks on our walk to them. We found four main springs and three smaller ones, all feeding two streams which ran about 150 yards $(135 \mathrm{~m})$ into the main creek. The highest temperature was $46^{\circ} \mathrm{C}$. but the water in the two streams cooled to $10^{\circ} \mathrm{C}$ before entering the creek. We collected some frogs' eggs from the same area, which showed no sign of human habitation and should be protected also.

Waring listed a hot spring on Lisianski Inlet, but we found only a trickle of water $6^{\circ} \mathrm{C}$ in temperature, issuing from under a $\log$ on a mud flat exactly at the village of Pelican. It followed a course not more than 2 inches $(5 \mathrm{~cm}$ ) wide and $1 / 2$ inch deep, with the outlet underwater at all times except low tide. Residents reported a small adjacent area which remains clear of snow during most of the winter, thus indicating the presence of some ground heat, though we could detect none with a thermometer.

We then went to White Sulphur,Springs, called Hooniah Spring by Waring, on the ocean side of Chichagof Island, the water from which issues directly on to the rocky shore. This area has been developed by the U.S. Forest Service as a recreation site, with a new cabin and bath house over the main spring which has a temperature of $44^{\circ} \mathrm{C}$ and produces a flow of about 25 gallons (110 litres) per minute. Two other very small springs $\left(35^{\circ} \mathrm{C}\right.$ and $\left.44^{\circ} \mathrm{C}\right)$ were found in the immediate area. These have little impact on

local biology since the waters from them flow almost directly into the ocean. They would not therefore be interesting for further study.

Time or logistics precluded our visiting other springs listed by Waring. Our vessel was not suitable for negotiating the Stickine River in spring flood. The springs at the south end of Vank Island and on the north arm of Peril Strait are evidently very small, and issue forth at the shore. We were advised that Lituya Bay is an extremely hazardous shore on which to beach.

Of those springs visited in southeastern Alaska, it is evident that the ones at the heads of Tenekee Inlet and Neka Bay are worthy of further study, and of inclusion into a system of land classification which would preserve them in their natural and unique state for future generations.

\author{
Joseph A. Nava \\ Institute of Arctic Biology \\ University of Alaska \\ Fairbanks, Alaska 99701 \\ U.S.A.
}

\section{REFERENCES}

1Nava, J. and Morrison, P. 1974. Notes on hot springs in the interior of Alaska. Arctic, 27(3): 241-3.

2Waring, G. A. 1917. Mineral springs of Alaska. U.S. Geological Survey, Water Supply Paper no. 418. 